\title{
Strategi Pengembangan Agroindustri Tempe di Kecamatan Balik Bukit Kabupaten Lampung Barat
}

\section{Development Strategy of Tempeh Agroindustry in Balik Bukit Sub- District, Lampung Barat District}

\author{
Nuraini ${ }^{*}$, Ktut Murniati ${ }^{1}$, Lina Marlina ${ }^{1}$ \\ ${ }^{1}$ Jurusan Agribisnis/Universitas Lampung \\ E-mail: nuraini.200299@gmail.com
}

\begin{abstract}
The purpose of this study is to analyze the development strategy of the tempe agroindustry. Survey was used for this research and Village Sebarus Balik Bukit, West Lampung, Lampung Province was chosen as the location of the research. The location was determined by using a purposive method because Balik Bukit District was the center of tempeh production in West Lampung Regency. Respondents were determined using the purposive sampling method with a total of 19 people, consisting of one person from the government (Liwa City Industry Office, Balik Bukit Subdistrict, West Lampung Regency), and 18 people consisting of one owner, two employees, and three consumers from each agroindustry scale. The data used were primary and secondary data collected in March 2020. The Primary data were obtained using questionnaires, while secondary data were obtained from related journals and publications. The data were analyzed using IFAS and EFAS matrix analysis methods and SWOT analysis. The results showed that tempeh agroindustries were on matrix I (aggressive strategy). Household-scale tempeh agroindustry development strategy was to increase the production of tempeh to a larger scale. The medium-scale tempeh agroindustry development strategy was to maintain the marketing of tempeh that has been quite extensive. The strategy of large-scale development of tempeh agroindustry was to expand the marketing of tempeh products out of the area.
\end{abstract}

Key words: agroindustry, strategy, SWOT, tempe

Disubmit : 10 Desember 2020, Diterima: 19 Mei 2021, Disetujui : 29 Oktober 2021

\section{PENDAHULUAN}

Tempe menjadi olahan yang dapat dikonsumsi oleh seluruh golongan masyarakat. Kandungan protein nabati dalam tempe menjadikan tempe sebagai "daging" bagi kelompok vegetarian. Konsumen tempe yang mencakup semua strata sosial ini menunjukkan potensi yang besar bagi industri pengolahan tempe. Pramayang, Haryono, dan Murniati (2020) menyatakan bahwa proses pembuatan tempe yang sangat mudah menyebabkan masyarakat banyak yang berprofesi sebagai pengrajin tempe. Salah satu lokasi yang paling banyak terdapat pengrajin tempe di Kabupaten Lampung Barat adalah Kecamatan Balik Bukit dengan jumlah pengrajin sebanyak 21 pengrajin, sehingga Kecamatan Balik Bukit dikatakan sebagai sentra agroindustri tempe di Kabupaten Lampung Barat. Kelurahan Sebarus merupakan kelurahan yang memiliki jumlah pengrajin tempe terbanyak diantara kelurahan lainnya yang ada di Kecamatan Balik Bukit yaitu berjumlah sebanyak 17 pengrajin (Dinas Koperindag Kabupaten Lampung Barat, 2019). Usaha tempe di 
Nuraini : Strategi Pengembangan Agroindustri Tempe .........

Kelurahan Sebarus tidak terlepas dari banyaknya kendala yang mengancam keberlangsungan usaha. Salah satu kendala yang dihadapi agroindustri tempe skala kecil adalah keterbatasan modal, minimnya keahlian dan keterampilan sumber daya manusia, serta penggunaan teknologi yang masih sederhana.

Jumlah pengrajin tempe yang sangat banyak di Kelurahan Sebarus mengakibatkan persaingan yang ketat antar agroindustri tempe, sehingga perlu penerapan strategi pengembangan yang tepat dan strategis agar para pengrajin tempe dapat mengembangkan usahanya. Penerapan srategi pengembangan yang tepat dapat mengatasi berbagai kendala yang dihadapi oleh para pengrajin. Kendala yang ditemui adalah pengrajin tempe yang belum sadar akan pentingnya merek dagang dan kualitas yang dihasilkan kurang baik (mudah hancur dan mudah bau). Pengrajin tempe menghasilkan produk yang cukup banyak, namun hanya menjual langsung ke konsumen dan melalui pedagang perantara, serta belum membuka kios di tempat lain. Kendala lain terdapat pada harga jual tempe yang mengikuti harga pengrajin lain di daerah sekitar, karena jika harga lebih tinggi dari pengrajin tempe lain, maka tempe yang diproduksi tidak terjual di pasar walaupun kualitas produk lebih tinggi dari pengrajin lain.

Agroindustri dalam pengembangan usahanya memiliki permasalahan dari sisi internal diantaranya yaitu tingginya biaya produksi. Bahan baku, berupa kedelai, yang digunakan agroindustri tidak dibeli langsung melalui agen, sehingga harga bahan baku cukup mahal. Suminartika (2020) mengemukakan bahwa 83,1 persen kebutuhan kedelai di Indonesia dipenuhi melalui kedelai impor. Kenaikan nilai tukar dolar juga merupakan salah satu penyebab utama tingginya tingkat harga kedelai. Pada umumnya, tingkat persaingan dari setiap industri yang sedang berkembang masih dalam kategori rendah, sehingga harus langsung diarahkan pada akar persoalannya dengan menggunakan beberapa strategi. Strategi yang tepat dengan kondisi dari setiap industri dapat meningkatkan kemampuan serta potensi yang di miliki. Penentu strategi dalam memahami serta mengidentifikasi factor-faktor lingkungan, dimana mereka menjalankan usahanya. Lingkungan adalah salah satu hal terpenting yang dapat menunjang keberhasilan, $\backslash$ dalam persaingan, baik pada lingkungan internal maupun lingkungan eksternal. Berdasarkan uraian masalah maka tujuan penelitian ini yaitu menganalisis kondisi lingkungan internal serta eksternal yang mempengaruhi pengembangan industri pengolahan tempe, serta menyusun strategi pengembangan industri pengolahan tempe di Balik Bukit Kabupaten Lampung Barat, Provinsi Lampung.

\section{METODE PENELITIAN}

Metode yang digunakan pada penelitian ini adalah metode survei. Metode survey dilakukan dengan pengamatan langsung di lapangan dan menelaah informasi awal mengenai usaha agroindustri tempe yang dijadikan sebagai responden. Metode survey juga digunakan untuk mendapatkan data secara lengkap, rinci, dan sistematis pada agroindustri tempe, mengenai strategi pengembangannya (Yolandika, Nurmalina and Suharno, 2017). Lokasi penelitian ditentukan secara sengaja (purposive) di Kelurahan Sebarus, Kecamatan Balik Bukit, Kabupaten Lampung Barat karena Kelurahan Sebarus memiliki jumlah pengrajin tempe terbanyak di Kecamatan Balik Bukit yaitu berjumlah 21 orang.

Penentuan responden dilakukan secara purposive sampling. Responden pada penelitian ini berjumlah 19 orang untuk meneliti agroindustri tempe pada tiga skala, yaitu rumah tangga, menengah, dan besar, yang terdiri dari satu orang dari pemerintah (Dinas Perindustrian Kota Liwa, Kecamatan Balik Bukit, Kabupaten Lampung Barat) dan setiap skalanya terdiri dari satu pemilik, dua karyawan, dan tiga konsumen. Penentuan skala agroindustri tempe ditentukan berdasarkan jumlah kapasitas produksi dan jumlah tenaga kerja. Jumlah minimal responden dalam penelitian strategi pengembangan adalah satu agroindustri, hal ini sesuai dengan penelitian Paley, Kembauw, dan Tuhumury (2021) yang melakukan penelitian mengenai strategi pengembangan dengan mengambil kasus di Agroindustri Kelapa UD Wootay. Penelitian ini menggunakan data primer dan data sekunder. Data primer diperoleh dari wawancara menggunakan kuesioner, pengamatan, serta pencatatan langsung tentang keadaan di lapangan, sedangkan data sekunder merupakan data yang 
diperoleh dari literatur yang berhubungan dengan penelitian dan data dari instansi-instansi terkait. Pengumpulan data dilakukan pada Bulan Maret 2020. Data dianalisis dengan metode analisis matriks IFAS dan EFAS serta analisis SWOT.

Untuk menyusunan strategi pengembangan pada penelitian ini menggunakan beberapa tahapan. Tahapan pertama adalah menentukan faktor lingkungan internal dan eksternal. Tahapan ke dua adalah pemberian bobot, serta perangkingan setiap komponen dengan menggunakan matriks EFAS dan IFAS dengan skala 0.00 (tidak penting) hingga 1.00 (paling penting). Tahapan ke tiga adalah menyilangkan tiap komponen dari hasil perangkingan antara matriks EFAS dan IFAS, sehingga dapat menghasilkan suatu strategi pengembangan. Tahapan ke empat adalah memberikan pembobotan terhadap strategi berdasarkan visi dan misi yang di miliki oleh agroindustri, sehingga dapat di peroleh 10 strategi prioritas tertinggi berdasarkan analisis SWOT. Tahapan pembobotan ini mengacu pada teori David (2004), yaitu dengan derajat kepentingan relative dengan menggunakan tabel catur. Penentuan bobot faktor eksternal dan factor internal dilakukan dengan cara memberikan pembobotan angka pada setiap faktor. Penilaian angka pembobotan adalah sebagai berikut, 2 (dua) jika faktor vertikal lebih penting dibandingkan faktor horizontal, 1 (satu) jika faktor vertikal dan horizontal memiliki tingkat kepentingan yang sama dan 0 jika faktor vertikal kurang penting dibandingkan faktor horizontal. Penyilangan matriks EFAS dan IFAS dapat menghasilkan 100 buah strategi. Strategi tersebut kemudian akan dikembalikan pada visi dan misi Dinas Koperasi UKM, Perindustrian, dan Perdagangan Kabupaten Lampung Barat, sehingga diperoleh 10 strategi prioritas berdasarkan analisis SWOT.

Penentuan komponen internal dan komponen eksternal yang digunakan mengacu pada teori David (2004). Faktor internal, yaitu: komponen, produk, pendanaan dan manajemen, SDM, pemasaran, dan lokasi agroindustry. Faktor eksternal, yaitu: komponen, sosial ekonomi dan budaya, pesaing, teknologi, konsumen, dan kebijakan pemerintah.. Strategi pengembangan pada agroindustri tempe dianalisis dengan menggunakan analisis SWOT. Lestari, Lestari, dan Suryani (2020) menjelaskan bahwa analisis SWOT menganalisis bagaimana memaksimalkan kekuatan dan peluang, meminimalkan kelemahan dan ancaman, serta merencanakan strategi yang harus diambil pada masa mendatang. Matriks tersebut akan menghasilkan empat kemungkinan strategi yaitu strategi SO, ST, WO dan WT. Berdasarkan hasil tersebut maka akan terpilih strategi yang sesuai dengan kuadran I, II, III dan IV pada diagram analisis SWOT. Apabila penyilangan strategi tersebut tidak sesuai dengan logika maka penyilangan strategi tersebut tidak dapat dianalisis lebih lanjut.

\section{HASIL DAN PEMBAHASAN}

\section{Karakteristik Responden}

Umur responden termasuk dalam umur produktif, baik pada skala rumah tangga (26-50 tahun), skala menengah (24-59 tahun), dan skala besar (26-60 tahun) sesuai dengan penelitina Subri (2012) yang menyatakan bahwa usia kerja produktif berkisar antara 15-64. Tingkat pendidikan pemilik, karyawan, dan konsumen pada ketiga skala agroindustri masih relatif rendah, yaitu SD, SMP, dan SMA. Responden dari pemerintah memiliki tingkat pendidikan yang relatif tinggi yaitu S1. Konsumen pada agroindustri skala rumah tangga sebagian besar adalah perempuan dan termasuk dalam golongan pendapatan sedang. Segmentasi pasar pada agroindustri tempe skala rumah tangga dan menengah adalah masyarakat menengah yang merupakan warga sekitar lokasi agroindustri tempe yang memiliki pendapatan sedang, sedangkan agroindustri skala besar adalah masyarakat menengah ke bawah dengan golongan pendapatan sedang.

\section{Analisis Lingkungan Internal Agroindustri Tempe}

Analisis lingkungan internal agroindustri tempe adalah faktor-faktor dari dalam agroindustri tempe yang berpengaruh pada posisi dan tindakan agroindustri, baik langsung maupun tidak langsung. Faktor 
Nuraini : Strategi Pengembangan Agroindustri Tempe .........

kekuatan dan kelemahan agroindustri tempe dengan skala rumah tangga, menengah dan besar didasarkan pada lima faktor menurut Sari, Haryono, dan Adawiyah (2017), yaitu produk, manajemen dan pendanaan, sumber daya manusia (SDM), lokasi usaha, serta pemasaran. Produk tempe harus memenuhi standar kualitas yang baik, agar dapat dipasarkan dan dikonsumsi oleh masyarakat. Standar kualitas yang baik tentunya memiliki tampilan, model, warna, cap dagang, pengemasan, labelnya, serta keawetannya. Agroindustri tempe yang baik adalah agroindustri yang sudah menerapkan manajemen dengan baik yang terdiri dari planning, organizing, actuating, serta controlling. Agroindustri harus sudah memiliki pencatatan pembukuan yang teratur dan rapih agar agroindustri dapat melihat perkembangan usahanya. Semakin baik keterampilan sumber daya manusia yang baik maka kualitas produk yang dihasilkan akan semakin baik, Lokasi usaha diukur dengan melihat strategis atau tidaknya lokasi usaha terhadap sumber bahan baku, tenaga kerja dan konsumen agroindustri. Pemasaran diukur dengan melihat luasnya jaringan pemasaran yang dijangkau oleh agroindustri.

\section{Analisis Lingkungan Internal Agroindustri Tempe Skala Rumah Tangga}

Rincian matriks faktor internal kekuatan dan kelemahan pada agroindustri tempe skala rumah tangga disajikan pada Tabel 1.

Tabel 1. Matriks faktor internal kekuatan dan kelemahan agroindustri tempe skala rumah tangga

\begin{tabular}{|c|c|c|c|c|c|}
\hline Komponen & Kekuatan/Kelemahan & Bobot & Rating & Skor & Rangking \\
\hline Produk & Produk yang dihasilkan berkualitas & 0,102 & 4 & 0,406 & 1 \\
\hline $\begin{array}{l}\text { Sumber Daya } \\
\text { Manusia }\end{array}$ & $\begin{array}{l}\text { Keterampilan yang baik telah dimiliki sumber daya } \\
\text { manusia }\end{array}$ & 0,105 & 3 & 0,314 & 2 \\
\hline Pemasaran & $\begin{array}{l}\text { Produk tempe sudah dipasarkan dengan baik dan diminati } \\
\text { tidak hanya masyarakat umum tetapi juga rumah sakit dan } \\
\text { supermarket }\end{array}$ & 0,097 & 3 & 0,291 & 3 \\
\hline $\begin{array}{l}\text { Manajemen \& } \\
\text { pendanaan }\end{array}$ & $\begin{array}{l}\text { Sudah dilakukan penerapan manajemen dan pencatatan } \\
\text { keuangan dengan baik }\end{array}$ & 0,095 & 3 & 0,286 & 4 \\
\hline Lokasi Usaha & Fasilitas jalan menuju lokasi agroindustri sudah beraspal & 0,084 & 3 & 0,253 & 5 \\
\hline Total kekuatan & & 0,483 & & $\mathbf{1 , 5 5 0}$ & \\
\hline $\begin{array}{l}\text { Manajemen \& } \\
\text { pendanaan }\end{array}$ & $\begin{array}{l}\text { Pembukuan mengenai pengeluaran dan penerimaan belum } \\
\text { ditulis secara tertib dan rapi }\end{array}$ & 0,105 & 3 & 0,314 & 1 \\
\hline $\begin{array}{l}\text { Sumber Daya } \\
\text { Manusia }\end{array}$ & Tenaga kerja berpendidikan rendah & 0,108 & 2 & 0,216 & 2 \\
\hline Produk & $\begin{array}{l}\text { Variasi produk kurang beragam dan belum dikemas dengan } \\
\text { baik }\end{array}$ & 0,103 & 2 & 0,206 & 3 \\
\hline Pemasaran & $\begin{array}{l}\text { Tidak ada kegiatan promosi untuk pengembangan } \\
\text { agroindustri tempe selanjutnya }\end{array}$ & 0,103 & 2 & 0,206 & 4 \\
\hline Lokasi Usaha & $\begin{array}{l}\text { Lokasi agroindustri terdapat di gang sempit sehingga tidak } \\
\text { dapat diakses menggunakan kendaraan yang besar }\end{array}$ & 0,098 & 2 & 0,197 & 5 \\
\hline Total kelemahan & & 0,517 & & 1,139 & \\
\hline
\end{tabular}

\section{Analisis Lingkungan Internal Agroindustri Tempe Skala Menengah}

Rincian matriks faktor internal kekuatan dan kelemahan pada agroindustri tempe skala menengah disajikan pada Tabel 2 .

Tabel 2. Matriks faktor internal kekuatan dan kelemahan agroindustri tempe skala menengah

\begin{tabular}{llcccc}
\hline Komponen & \multicolumn{1}{c}{ Kekuatan/Kelemahan } & Bobot & Rating & Skor & Rangking \\
\hline Produk & Produk yang dihasilkan berkualitas & 0,098 & 4 & 0,394 & 1 \\
Lokasi Usaha & Fasilitas jalan menuju lokasi agroindustri sudah beraspal & 0,109 & 3 & 0,328 & 2 \\
Pemasaran & $\begin{array}{l}\text { Produk tempe sudah dipasarkan dengan baik dan diminati } \\
\text { tidak hanya masyarakat umum tetapi juga rumah sakit dan } \\
\text { supermarket }\end{array}$ & 0,100 & 3 & 0,300 & 3 \\
Manajemen \& & $\begin{array}{l}\text { Sudah dilakukan penerapan manajemen dan pencatatan } \\
\text { kendanaan }\end{array}$ & 0,097 & 3 & \multirow{2}{*}{0,291} & \multirow{2}{*}{4} \\
Sumber Daya & Keterampilan yang baik telah dimiliki sumber daya manusia & 0,097 & 3 & 0,291 & 5 \\
\hline
\end{tabular}




\begin{tabular}{|c|c|c|c|c|c|}
\hline \multicolumn{2}{|l|}{ Total kekuatan } & \multicolumn{2}{|l|}{$\mathbf{0 , 5 0 2}$} & \multicolumn{2}{|l|}{1,603} \\
\hline $\begin{array}{l}\text { Manajemen \& } \\
\text { pendanaan }\end{array}$ & $\begin{array}{l}\text { Pembukuan mengenai pengeluaran dan penerimaan belum } \\
\text { ditulis secara tertib dan rapi }\end{array}$ & 0,098 & 3 & 0,295 & 1 \\
\hline Produk & $\begin{array}{l}\text { Variasi produk kurang beragam dan belum dikemas dengan } \\
\text { baik }\end{array}$ & 0,109 & 2 & 0,219 & 2 \\
\hline Lokasi Usaha & $\begin{array}{l}\text { Lokasi agroindustri terdapat di gang sempit sehingga tidak } \\
\text { dapat diakses menggunakan kendaraan yang besar }\end{array}$ & 0,103 & 2 & 0,206 & 3 \\
\hline Pemasaran & $\begin{array}{l}\text { Tidak ada kegiatan promosi untuk pengembangan agroindustri } \\
\text { tempe selanjutnya }\end{array}$ & 0,095 & 2 & 0,191 & 4 \\
\hline $\begin{array}{l}\text { Sumber Daya } \\
\text { Manusia }\end{array}$ & Tenaga kerja berpendidikan rendah & 0,092 & 2 & 0,184 & 5 \\
\hline \multicolumn{2}{|c|}{ Total kelemahan } & 0,498 & & $\mathbf{1 , 0 9 5}$ & \\
\hline
\end{tabular}

\section{Analisis Lingkungan Internal Agroindustri Tempkala Menengah}

Rincian matriks faktor internal kekuatan dan kelemahan pada agroindustri tempe skala besar disajikan pada Tabel 3.

Tabel 3. Matriks faktor internal kekuatan dan kelemahan agroindustri tempe skala besar

\begin{tabular}{|c|c|c|c|c|c|}
\hline Komponen & Kekuatan/Kelemahan & Bobot & Rating & Skor & Rangking \\
\hline Produk & Produk yang dihasilkan berkualitas & 0,105 & 4 & 0,419 & 1 \\
\hline Pemasaran & $\begin{array}{l}\text { Produk tempe sudah dipasarkan dengan baik dan diminati } \\
\text { tidak hanya masyarakat umum tetapi juga rumah sakit dan } \\
\text { supermarket }\end{array}$ & 0,103 & 3 & 0,310 & 2 \\
\hline $\begin{array}{l}\text { Manajemen \& } \\
\text { pendanaan }\end{array}$ & $\begin{array}{l}\text { Sudah dilakukan penerapan manajemen dan pencatatan } \\
\text { keuangan dengan baik }\end{array}$ & 0,103 & 3 & 0,309 & 3 \\
\hline Lokasi Usaha & Fasilitas jalan menuju lokasi agroindustri sudah beraspal & 0,103 & 3 & 0,309 & 4 \\
\hline $\begin{array}{l}\text { Sumber Daya } \\
\text { Manusia }\end{array}$ & Keterampilan yang baik telah dimiliki sumber daya manusia & 0,106 & 2 & 0,213 & 5 \\
\hline Total kekuatan & & $\mathbf{0 , 5 2 0}$ & & $\mathbf{1 , 5 6 0}$ & \\
\hline $\begin{array}{l}\text { Manajemen \& } \\
\text { pendanaan }\end{array}$ & $\begin{array}{l}\text { Pembukuan mengenai pengeluaran dan penerimaan belum } \\
\text { ditulis secara tertib dan rapi }\end{array}$ & 0,089 & 3 & 0,267 & 1 \\
\hline Produk & $\begin{array}{l}\text { Variasi produk kurang beragam dan belum dikemas dengan } \\
\text { baik }\end{array}$ & 0,098 & 2 & 0,197 & 2 \\
\hline Lokasi Usaha & $\begin{array}{l}\text { Lokasi agroindustri terdapat di gang sempit sehingga tidak } \\
\text { dapat diakses menggunakan kendaraan yang besar }\end{array}$ & 0,092 & 1 & 0,092 & 3 \\
\hline Pemasaran & $\begin{array}{l}\text { Tidak ada kegiatan promosi untuk pengembangan } \\
\text { agroindustri tempe selanjutnya }\end{array}$ & 0,105 & 2 & 0,210 & 4 \\
\hline $\begin{array}{l}\text { Sumber Daya } \\
\text { Manusia }\end{array}$ & Tenaga kerja berpendidikan rendah & 0,095 & 2 & 0,191 & 5 \\
\hline Total kelemahan & & $\mathbf{0 , 4 8 0}$ & & 0,956 & \\
\hline
\end{tabular}

Tabel 1, 2, dan 3 menunjukkan bahwa kekuatan dan kelemahan agroindustri tempe pada skala rumah tangga, menengah, dan besar sama. Kekuatan agroindustri terletak pada produk yang berkualitas, karena dapat mempertahankan kesetiaan dari pembelian konsumen tempe. Hal ini dapat dilihat dari tampilan produk tempe yang memiliki permukaan yang diselimuti oleh serabut kecil berupa jamur berwarna putih susu. Jamur putih bertekstur halus di permukaannya menandakan bahwa tempe masih dalam keadaan segar, selain itu agroindustri tempe di Kelurahan Sebarus sudah mempunyai label dan merk dagang masing-masing. Hasil penelitian ini sejalan dengan Purwono, Sugyaningsih, dan Putri (2015) yang mengemukakan bahwa produk yang berkualitas menjadi kekuatan terbesar bisnis rumah tangga tempe di Kota Bogor. Kelemahan yang paling besar adalah komponen manajemen dan pendanaan, karena pembukuan mengenai pengeluaran dan penerimaan pada seluruh agroindustri tempe belum ditulis secara tertib dan rapi, hal ini membuat pemilik kesulitan dalam membandingkan kondisi usahanya pada saat ini dengan tahun-tahun yang sebelumnya. Hasil penelitian ini sejalan dengan Kusumawati, Astawan, dan Prangdimurti (2020) dan Arum, Widjaya, dan Marlina (2017) yang mengemukakan bahwa pengrajin tempe di Kota Bogor dan Kabupaten Pringsewu tidak memiliki pembukuan yang teratur. 


\section{Analisis Lingkungan Eksternal Agroindustri Tempe}

Analisis pada lingkungan eksternal agroindustri tempe merupakan analisis faktor dari luar agroindustri tempe, baik berupa peluang maupun ancaman. Faktor-faktor eksternal didasarkan pada empat komponen yang terdiri dari, sosial ekonomi budaya dan teknologi, kebijakan pemerintah, pesaing, dan konsumen.

\section{Analisis Lingkungan Eksternal Agroindustri Tempe Skala Rumah Tangga}

Matriks faktor eksternal untuk peluang dan ancaman agroindustri skala rumah tangga disajikan pada Tabel 4. Berdasarkan Tabel 4 peluang yang paling besar adalah komponen ekonomi, sosial, budaya dan teknologi dengan skor 0,413 dan rating 4. Ancaman yang paling besar adalah komponen kebijakan pemerintah dengan skor 0,305 dan rating 3 , hal ini karena masih kurangnya pengawasan dari pemrintah dan masih minimnya kebijakan pemerintah yang mengatur mengenai agroindustri tempe, hasil penelitian ini sejalan dengan Ningtyas (2021) yang menunjukan bahwa ancaman terbesar agroindustri tempe adalah kebijakan pemerintah, hal ini dikarenakan masih belum adanya kebijakan untuk menstabilkan harga kedelai sebagai bahan baku utama tempe.

Tabel 4. Matriks faktor eksternal peluang dan ancaman agroindustri tempe skala rumah tangga

\begin{tabular}{|c|c|c|c|c|c|}
\hline Komponen & Peluang/Ancaman & Bobot & Rating & Skor & Rangking \\
\hline $\begin{array}{l}\text { Ekonomi, sosial, \& } \\
\text { budaya }\end{array}$ & Tempe diminati oleh berbagai lapisan masyarakat & 0,103 & 4 & 0,413 & 1 \\
\hline Teknologi & $\begin{array}{l}\text { Adanya teknologi alat mesin produksi yang } \\
\text { mempercepat waktu produksi }\end{array}$ & 0,103 & 3 & 0,309 & 2 \\
\hline Pesaing & Daya saing produk tinggi & 0,094 & 3 & 0,281 & 3 \\
\hline Konsumen & $\begin{array}{l}\text { Banyaknya konsumen yang menyukai tempe karena } \\
\text { bersertifikat halal dan tentunya aman untuk } \\
\text { dikonsumsi }\end{array}$ & 0,092 & 3 & 0,276 & 4 \\
\hline $\begin{array}{l}\text { Kebijakan } \\
\text { pemerintah }\end{array}$ & Memanfaatkan dukungan dari pemerintah & 0,109 & 2 & 0,219 & 5 \\
\hline Total peluang & & $\mathbf{0 , 5 2 0}$ & & 1,499 & \\
\hline $\begin{array}{l}\text { Kebijakan } \\
\text { pemerintah }\end{array}$ & Kurangnya pengawasan dari pemerintah & 0,102 & 3 & 0,305 & 1 \\
\hline Pesaing & Banyaknya pesaing sejenis yang masuk ke pasar & 0,100 & 3 & 0,300 & 2 \\
\hline Teknologi & $\begin{array}{l}\text { Perkembangan teknologi sulit diikuti karena } \\
\text { memerlukan biaya yang cukup tinggi }\end{array}$ & 0,105 & 2 & 0,209 & 3 \\
\hline Konsumen & $\begin{array}{l}\text { Banyaknya produk tempe lain yang ditawarkan } \\
\text { kepada konsumen dan masih ada agroindustri tempe } \\
\text { yang belum bersertifikat halal }\end{array}$ & 0,097 & 2 & 0,194 & 4 \\
\hline $\begin{array}{l}\text { Ekonomi, sosial, \& } \\
\text { budaya }\end{array}$ & $\begin{array}{l}\text { Kenaikan harga bahan baku mempengaruhi biaya } \\
\text { produksi }\end{array}$ & 0,095 & 2 & 0,190 & 5 \\
\hline Total ancaman & & 0,498 & & 1,198 & \\
\hline
\end{tabular}

\section{Analisis Lingkungan Eksternal Agroindustri Tempe Skala Menengah}

Matriks faktor eksternal untuk peluang dan ancaman agroindustri skala menengah disajikan pada Tabel 5. Berdasarkan Tabel 5 dapat diketahui bahwa peluang yang paling besar adalah komponen ekonomi, sosial, budaya dan teknologi dengan skor 0,394 dan rating 4, sedangkan ancaman yang paling besar adalah komponen pesaing dengan skor 0,333 dan rating 3, hal ini karena munculnya pesaing sejenis yang masuk ke pasar membuat persaingan menjadi semakin meningkat. Semakin banyaknya pesaing sejenis yang masuk ke pasar, semakin banyak pula produk sejenis lainnya yang ditawarkan kepada konsumen. Banyaknya pesaing dapat dilihat dari jumlah agroindustri tempe yang ada di Kelurahan Sebarus cukup banyak yang berjumlah 17 agroindustri. 
Tabel 5. Matriks faktor eksternal peluang dan ancaman agroindustri tempe skala menengah

\begin{tabular}{|c|c|c|c|c|c|}
\hline Komponen & Peluang/Ancaman & Bobot & Rating & Skor & Rangking \\
\hline $\begin{array}{l}\text { Ekonomi, sosial, \& } \\
\text { budaya }\end{array}$ & Tempe diminati oleh berbagai lapisan masyarakat & 0,098 & 4 & 0,394 & 1 \\
\hline $\begin{array}{l}\text { Kebijakan } \\
\text { pemerintah }\end{array}$ & Memanfaatkan dukungan dari pemerintah & 0,103 & 3 & 0,310 & 2 \\
\hline Pesaing & Daya saing produk tinggi & 0,098 & 3 & 0,295 & 3 \\
\hline Teknologi & $\begin{array}{l}\text { Adanya teknologi alat mesin produksi yang } \\
\text { mempercepat waktu produksi }\end{array}$ & 0,095 & 3 & 0,286 & 4 \\
\hline Konsumen & $\begin{array}{l}\text { Banyaknya konsumen yang menyukai tempe karena } \\
\text { bersertifikat halal dan tentunya aman untuk dikonsumsi }\end{array}$ & 0,091 & 2 & 0,181 & 5 \\
\hline Total peluang & & 0,486 & & 1,465 & \\
\hline Pesaing & Banyaknya pesaing sejenis yang masuk ke pasar & 0,111 & 3 & 0,333 & 1 \\
\hline $\begin{array}{l}\text { Kebijakan } \\
\text { pemerintah }\end{array}$ & Kurangnya pengawasan dari pemerintah & 0,087 & 3 & 0,262 & 2 \\
\hline $\begin{array}{l}\text { Ekonomi, sosial, \& } \\
\text { budaya }\end{array}$ & $\begin{array}{l}\text { Kenaikan harga bahan baku mempengaruhi biaya } \\
\text { produksi }\end{array}$ & 0,106 & 2 & 0,213 & 3 \\
\hline Teknologi & $\begin{array}{l}\text { Perkembangan teknologi sulit diikuti karena } \\
\text { memerlukan biaya yang cukup tinggi }\end{array}$ & 0,105 & 2 & 0,209 & 4 \\
\hline Konsumen & $\begin{array}{l}\text { Banyaknya produk tempe lain yang ditawarkan kepada } \\
\text { konsumen dan masih ada agroindustri tempe yang } \\
\text { belum bersertifikat halal }\end{array}$ & 0,103 & 2 & 0,207 & 5 \\
\hline Total ancaman & & $\mathbf{0 , 5 1 3}$ & & 1,224 & \\
\hline
\end{tabular}

\section{Analisis Lingkungan Eksternal Agroindustri Tempe Skala Besar}

Rincian matriks faktor eksternal untuk peluang dan ancaman agroindustri skala besar disajikan pada Tabel 6.

Tabel 6. Matriks faktor eksternal peluang dan ancaman agroindustri tempe skala besar

\begin{tabular}{|c|c|c|c|c|c|}
\hline Komponen & Peluang/Ancaman & Bobot & Rating & Skor & Rangking \\
\hline $\begin{array}{l}\text { Ekonomi, sosial, \& } \\
\text { budaya }\end{array}$ & Tempe diminati oleh berbagai lapisan masyarakat & 0,106 & 4 & 0,425 & 1 \\
\hline $\begin{array}{l}\text { Kebijakan } \\
\text { pemerintah }\end{array}$ & Memanfaatkan dukungan dari pemerintah & 0,114 & 3 & 0,342 & 2 \\
\hline Teknologi & $\begin{array}{l}\text { Adanya teknologi alat mesin produksi yang } \\
\text { mempercepat waktu produksi }\end{array}$ & 0,100 & 3 & 0,300 & 3 \\
\hline Pesaing & Daya saing produk tinggi & 0,089 & 3 & 0,267 & 4 \\
\hline Konsumen & $\begin{array}{l}\text { Banyaknya konsumen yang menyukai tempe karena } \\
\text { bersertifikat halal dan tentunya aman untuk dikonsumsi }\end{array}$ & 0,102 & 2 & 0,203 & 5 \\
\hline Total peluang & & $\mathbf{0 , 5 1 1}$ & & $\mathbf{1 , 5 3 8}$ & \\
\hline Pesaing & Banyaknya pesaing sejenis yang masuk ke pasar & 0,122 & 3 & 0,367 & 1 \\
\hline $\begin{array}{l}\text { Kebijakan } \\
\text { pemerintah }\end{array}$ & Kurangnya pengawasan dari pemerintah & 0,087 & 3 & 0,262 & 2 \\
\hline $\begin{array}{l}\text { Ekonomi, sosial, \& } \\
\text { budaya }\end{array}$ & $\begin{array}{l}\text { Kenaikan harga bahan baku mempengaruhi biaya } \\
\text { produksi }\end{array}$ & 0,097 & 2 & 0,194 & 3 \\
\hline Konsumen & $\begin{array}{l}\text { Banyaknya produk tempe lain yang ditawarkan } \\
\text { kepada konsumen dan masih ada agroindustri } \\
\text { tempe yang belum bersertifikat halal }\end{array}$ & 0,092 & 2 & 0,184 & 4 \\
\hline Teknologi & $\begin{array}{l}\text { Perkembangan teknologi sulit diikuti karena } \\
\text { memerlukan biaya yang cukup tinggi }\end{array}$ & 0,091 & 2 & 0,181 & 5 \\
\hline
\end{tabular}

Keterangan pemberian rating (kekuatan/kelemahan):

$4=$ Kekuatan/kelemahan yang dimiliki agroindustri sangat kuat/kelemahan yang dimiliki agroindustri sangat mudah dipecahkan

$3=$ Kekuatan/kelemahan yang dimiliki agroindustri kuat/kelemahan yang dimiliki agroindustri kuat

$2=$ Kekuatan/kelemahan yang dimiliki agroindustri rendah/kelemahan yang dimiliki agroindustri sulit dipecahkan

$1=$ Kekuatan/kelemahan yang dimiliki agroindustri sangat rendah/kelemahan yang dimiliki agroindustri sangat sulit dipecahkan 


\section{Nuraini : Strategi Pengembangan Agroindustri Tempe ........}

Berdasarkan Tabel 6 dapat diketahui bahwa peluang yang paling besar pada agroindustri adalah komponen ekonomi, sosial, budaya dan teknologi dengan skor 0,425 dan rating 4, hal ini dikarenakan tempe dapat dikonsumsi oleh semua strata sosial. Hasil penelitian ini sejalan dengan Febriatmoko, Aquina, dan Hardiyanti (2019) yang menunjukan bahwa salah satu keunggulan terbesar tempe dapat dikonsumsi oleh seluruh kalangan yang membuat peluang usaha tempe sangat besar dan menguntungkan. sedangkan ancaman yang paling besar adalah komponen pesaing dengan skor 0,367 dan rating 3. Hssil penelitian ini sejalan dengan Aziz, Jansen, dan Aliridla (2020) yang menunjukan bahwa agroindustri tempe merupakan salah satu agroindustri yang memiliki banyak pesaing, hal ini disebabkan karena besarnya konsumsi tempe di masyarakat, harga tempe yang terjangkau dan rasanya yang enak juga menjadi alasan utama tingginya konsumsi tempe di masyarakat. Tingginya permintaan akan tempe membuat para pengusaha berlombalomba untuk melakukan usaha pengolahan kedelai menjadi tempe.

\section{Strategi Pengembangan Agroindustri Tempe}

Selisih antara matriks IFAS dan EFAS dinyatakan pada diagram SWOT yang akan menggambarkan kondisi agroindustri terletak di bagian mana. Pembobotan diagram SWOT agroindustri tempe disajikan pada Tabel 7.

\section{Tabel 7. Pembobotan diagram SWOT agroindustri tempe}

\begin{tabular}{lcccccc}
\hline \multirow{2}{*}{ Skala Usaha } & \multicolumn{3}{c}{ Faktor Internal } & \multicolumn{3}{c}{ Faktor Eksternal } \\
\cline { 2 - 7 } & Kekuatan & Kelemahan & Selisih & Peluang & Ancaman & Selisih \\
\hline Skala rumah tangga & 1,550 & 1,139 & 0,411 & 1,499 & 1,198 & 0,300 \\
Skala menengah & 1,603 & 1,095 & 0,508 & 1,465 & 1,224 & 0,242 \\
Skala besar & 1,560 & 0,956 & 0,604 & 1,538 & 1,188 & 0,350 \\
\hline
\end{tabular}

Tabel 7 menunjukkan adanya selisih pada faktor internal dan eksternal yang menunjukan nilai positif, hal ini berarti pada ketiga skala agroindustry tempe kekuatan dan peluang yang dimiliki dapat mengetasi kelemahan dan ancaman yang dihadapi oleh agroindustri. Berdasarkan hal tersebut dapat dijelaskan bahwa strategi pengembangan yang diperoleh adalah strategi SO (Strength - Opportunity). Hal ini sejalan dengan Rusman, Hamdana, dan Sanusi (2020) mengenai usaha sapi potong di Kabupaten Maros yang juga menunjukkan selisih yang positif pada faktor internal dan eksternal. Berdasarkan Tabel 7 dapat dibuat diagram SWOT yang disajikan pada Gambar 1.

III. Stability

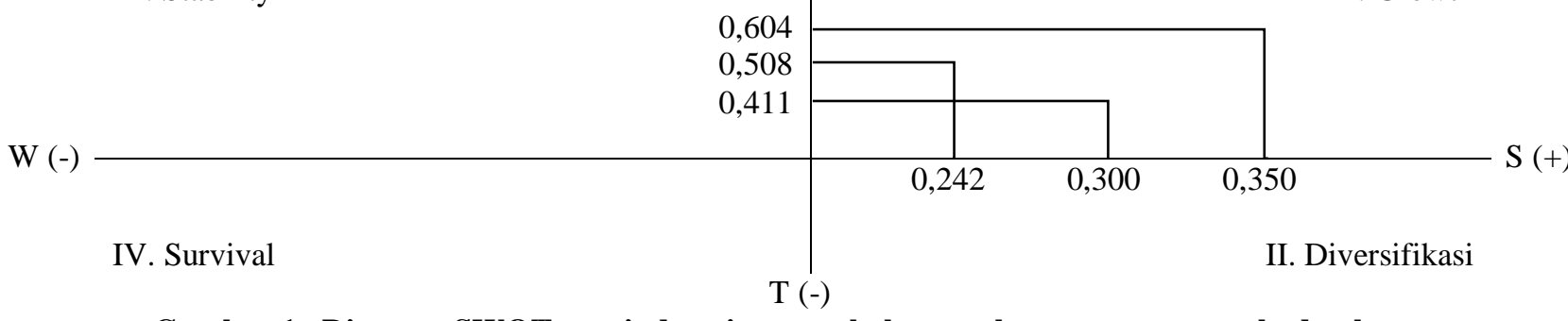

Gambar 1. Diagram SWOT agroindustri tempe skala rumah tangga, menengah, dan besar

Gambar 1 menunjukkan bahwa ketiga skala agroindustri tempe berada pada kuadran I (strategi agresif/growth) artinya situasi sangat menguntungkan, karena memiliki kekuatan sehingga dapat memanfaatkan peluang yang ada secara optimal. Strategi yang harus diterapkan dalam kondisi ini adalah mendukung kebijakan pertumbuhan yang agresif. Strategi pengembangan agroindustri tempe skala rumah tangga adalah pengembangan produksi tempe ke skala yang lebih besar karena tempe diminati berbagai 
kalangan masyarakat. Strategi pengembangan agroindustri tempe skala menengah adalah mempertahankan pemasaran yang sudah cukup luas karena tempe diminati oleh berbagai lapisan masyarakat. Strategi pengembangan agroindustri tempe skala besar adalah memperluas pemasaran produk tempe keluar daerah karena tempe diminati oleh berbagai lapisan masyarakat. Penelitian ini sejalan dengan penelitian Lamefa, Sukardi, dan Raharja (2020) mengenai agroindustri kopi di Kabupaten Kerinci dan penelitian Puspanegara, Ismono, dan Kasymir (2020) mengenai agroindustri beras siger di Kabupaten Lampung Timur dan Kabupaten Pringsewu yang juga berada pada kuadran I dan menyatakan strategi pada kuadran ini adalah strategi yang mengarah pada inovasi yang dapat memperluas jaringan dan mengembangkan agroindustri.

\section{Strategi Prioritas Agroindustri Tempe}

Berdasarkan indikator faktor internal dan faktor eksternal didapatkan strategi prioritas agroindustri tempe skala rumahtangga, menengah, dan besar, (1) Produk yang dihasilkan berkualitas sehingga tempe diminati oleh setiap lapisan masyarakat, (2) Produk berkualitas karena teknologi pada mesin untuk produksi yang dapat membuat waktu untuk memproduksi menjadi lebih cepat, (3) Produk yang dihasilkan berkualitas sehingga daya saing produk tinggi, (4) Keterampilan sumber daya manusia yang baik, (5) Keterampilan sumber daya manusia yang baik dengan memanfaatkan dukungan dari pemerintah, (6) Fasilitas jalan menuju lokasi agroindustri sudah beraspal dan adanya teknologi mesin produksi yang dapat membuat waktu untuk memproduksi menjadi lebih cepat, (7) Produk tempe sudah dipasarkan dengan baik dan ternyata diminati tidak hanya oleh masyarakat umum, tetapi juga supermarket dan rumahsakit, (8) Produk tempe sudah dipasarkan dengan baik dan diminati tidak hanya masyarakat umum tetapi juga rumah sakit dan supermarket karena adanya teknologi produksi sehingga waktu produksi lebih cepat, (9) Produk tempe sudah dipasarkan dengan baik dan ternyata diminati tidak hanya oleh masyarakat umum, tetapi juga supermarket dan rumahsakit karena banyaknya konsumen yang menyukai produk tempe karena bersertifikat halal dan tentunya aman untuk dikonsumsi, dan (10) Produk yang dihasilkan berkualitas dan banyaknya pesaingpesaing sejenis yang masuk ke dalam pasar.

\section{KESIMPULAN DAN SARAN \\ Kesimpulan}

Strategi pengembangan pada agroindustri tempe skala rumahtangga, yaitu pengembangan produksi tempe ke skala yang lebih besar, mengingat tempe sangat diminati berbagai kalangan masyarakat. Strategi pengembangan agroindustri tempe skala menengah yatu, diharapkan dapat mempertahankan atau meningkatkan pemasaran yang sudah cukup luas, megingat tempe sangat diminati oleh berbagai lapisan masyarakat. Strategi pengembangan agroindustri tempe skala besar adalah: meperluas area pemasaran produk tempe, mengingat tempe sangat diminati oleh berbagai lapisan masyarakat.

\section{Saran}

Agroindustri tempe skala rumah tangga, menengah, dan besar perlu melakukan pembukuan serta pencatatan mengenai penerimaan dan pengeluaran secara sistematis untuk mengurangi nilai kerugian. Pemerintah dapat terus melaksanakan kegiatan pembinaan bagi agroindustri.

\section{DAFTAR PUSTAKA}

Arum, W. P., Widjaya, S. and Marlina, L. (2017) 'Kelayakan Usaha dan Nilai Tambah Agroindustri Tempe', JIIA, 5(2), pp. 171-178.

Kusumawati, I., Astawan, M. and Prangdimurti, E. (2020) 'Efisiensi Proses Produksi dan Karakteristik Tempe dari Kedelai Pecah Kulit', Jurnal Pangan, 29(2), pp. 117-126. 
Nuraini : Strategi Pengembangan Agroindustri Tempe

Lamefa, D. Y., Sukardi and Raharja, S. (2020) 'Strategi Pengembangan Agroindustri Kopi di Kabupaten Kerinci', Jurnal AIP, 8(2), pp. 85-98.

Lestari, N. F. I., Lestari, D. A. H. and Suryani, A. (2020) 'Kepuasan, Loyalitas Konsumen, dan Strategi Pengembangan Agroindustri Kerupuk Bawang di Kota Bandar Lampung', JIIA, 8(3), pp. 446-452.

Pramayang, V., Haryono, D. and Murniati, K. (2020) 'Pendapatan dan Nilai Tambah Agroindustri Tempe di Kecamatan Punggur, Kabupaten Lampung Tengah', JIIA, 8(3), pp. 490-495.

Puspanegara, R. R., Ismono, R. H. and Kasymir, E. (2020) 'Strategi Pengembangan Agroindustri Beras Siger di Desa Wonokarto Kecamatan Sekampung, Kabupaten Lampung Timur, dan Desa Margosari, Kecamatan Pagelaran Utara, Kabupaten Pringsewu', JIIA, 8(3), pp. 374-379.

Rusman, R. F. Y., Hamdana, A. and Sanusi, A. (2020) 'Strategi Pengembangan Usaha Ternak Sapi Potong di Kecamatan Lau Kabupaten Maros’, JBMI, 17(2), pp. 119-129.

Sari, A. M., Haryono, D. and Adawiyah, R. (2017) 'Kinerja Produksi Dan Strategi Pengembangan Agroindustri Kopi Bubuk Di Kota Bandar Lampung', JIIA, 5(4), pp. 360-367.

Suminartika, E. (2020) 'Penggunaan Input yang Optimal pada Usaha Tani Kedelai (Suatu Kasus di Desa Sukahurip, Kecamatan Pangatikan, Kabupaten Garut, Jawa Barat)', Jurnal Ilmu Pertanian Indonesia, 25(4), pp. 556-563.

Yolandika, C., Nurmalina, R. and Suharno, S. (2017) 'Rantai Pasok Brokoli di Kecamatan Lembang Kabupaten Bandung Barat dengan Pendekatan Food Supply Chain Networks', Jurnal Penelitian Pertanian Terapan, 16(3), pp. 155-162. doi: 10.25181/jppt.v16i3.93. 